\title{
Marker controlled screening of resistant to red stele root rot (Rpf1 gene) strawberry selected forms
}

\author{
Alexander Lyzhin*, and Irina Luk'yanchuk \\ "I.V. Michurin Federal Scientific Center", 393774 Michurinsk, Russian Federation
}

\begin{abstract}
The results of the analysis of allelic polymorphism of the Rpfl red stele root rot resistance gene in strawberry hybrid forms using diagnostic DNA markers were shown. The recessive homozygous genotype (rpflrpfl) was identified in strawberry seedlings 932-29 ( $F$. virginiana subsp. platypetala (Rydb.) Staudt $\times$ Feyerverk), 933-4 $(F$. virginiana subsp. platypetala (Rydb.) Staudt $\times$ Rubinovyy kulon), 62- 7, 62-23 (Bylinnaya $\times$ Feyerverk), 65-2, 65-15 (Olimpiyskaya nadezhda $\times$ Bylinnaya) and 35-16 (922-67 $\times$ Maryshka). The heterozygous state of the Rpf1 gene was identified in strawberry forms 69-29 (Feyerverk $\times$ Bylinnaya), 62-41 (Bylinnaya $\times$ Feyerverk), 72-24, $72-71$ (Privlekatelnaya $\times$ Bylinnaya), 65-17, 65-24 (Olimpiyskaya nadezhda $\times$ Bylinnaya), which allows them to be used in breeding for resistance to $P$. fragariae var. fragariae as valuable initial forms.
\end{abstract}

\section{Introduction}

Phytophthora fragariae var. fragariae Hickman is the causative agent of red stele root rot, one of the most dangerous strawberry fungal diseases $[1,2]$. According to the list of the European and Mediterranean Plant Protection Organization (EPPO), P. fragariae var. fragariae has been A2 quarantine pathogen status [3].

Symptoms of red stele root rot of strawberry plants include reddening of the axial cylinder and death of root tips, inhibition of growth, wilting and death of plants $[4,5]$.

Resistance red stele root rot in strawberry varieties and forms is due to the presence of race-specific oligogens in the genome [6], of which the $R p f 1, \operatorname{Rpf} 2$, and $\operatorname{Rpf} 3$ genes make the greatest contribution to the formation of resistance [7].

Identification of genetic determinants of strawberry resistance to $P$. fragariae var. fragariae allows for targeted screening of resistant genotypes using diagnostic DNA markers $[8,9]$.

The purpose of this study was the analyze allelic polymorphism of the Rpfl red stele root rot resistance gene in strawberry hybrid seedlings for identify and involve valuable forms in the breeding programs to create resistant to fungal pathogens strawberry genotypes.

\footnotetext{
* Corresponding author: Ranenburzhetc@yandex.ru
} 


\section{Materials and methods}

The studies were carried out in 2020-2021. Biological material was represented by promising strawberry hybrid seedlings obtained at the "I.V. Michurin Federal Scientific Center".

Total genomic DNA of strawberry genotypes was extracted using the DArT method with modifications $[10,11]$.

Alleles of the Rpfl gene in the strawberry genome were identified by DNA analysis using diagnostic markers OPO-16C (5'-TCGGCGGTTC-3') [12] and SCAR-R1A (for 5'TGCATCATTAATGTAGAAGTCTTT-3', rev 5'TGATGCGACATACAAAAATATTAG-3') [8].

The SCAR-R1A marker (285 bp amplicon) corresponds to the Rpf1 resistance allele, and the target fragment is synthesized only if Rpfl allele is present in the strawberry genome. The OPO-16C marker (438 bp amplicon) corresponds to the non-functional $r p f 1$ allele. The combination of these markers makes it possible to identify the allelic state of the Rpfl gene in the studied strawberry genotypes [13].

The reaction mix for PCR in total volume of $15 \mu \mathrm{L}$ contained:

- SCAR-R1A marker: $1.5 \mu$ Taq-buffer, $2.0 \mathrm{mM}$ of each deoxyribonucleotide triphosphate, $2.5 \mathrm{mM}$ magnesium chloride, $0.2 \mathrm{U}$ Taq DNA polymerase, $0.2 \mu \mathrm{M}$ of each primer and $20 \mathrm{ng}$ of genomic DNA;

- OPO-16C marker: $1.5 \mu \mathrm{l}$ Taq-buffer, $0.8 \mathrm{mM}$ of each deoxyribonucleotide triphosphate, $2.5 \mathrm{mM}$ magnesium chloride, $0.3 \mathrm{U}$ Taq DNA polymerase, $0.5 \mu \mathrm{M}$ primer and $100 \mathrm{ng}$ of genomic DNA.

The amplification was performed in T100 Thermal Cycler (BioRad) according to the programs:

- OPO-16C marker: $5 \mathrm{~min}$ denaturation at $94^{\circ} \mathrm{C}$ followed by 36 cycles of $30 \mathrm{~s}$ at $94^{\circ} \mathrm{C}$, $45 \mathrm{~s}$ at $34^{\circ} \mathrm{C}$ and $60 \mathrm{~s}$ at $72^{\circ} \mathrm{C}$, followed by a final extension step of $5 \mathrm{~min}$ at $72^{\circ} \mathrm{C}$;

- SCAR-R1A marker: 3 min denaturation at $94^{\circ} \mathrm{C}$ followed by 25 cycles of $30 \mathrm{~s}$ at $94^{\circ} \mathrm{C}$, $45 \mathrm{~s}$ at $60^{\circ} \mathrm{C}$ and $60 \mathrm{~s}$ at $72^{\circ} \mathrm{C}$, followed by a final extension step of $7 \mathrm{~min}$ at $72^{\circ} \mathrm{C}$.

Amplification products were separated by electrophoretic method in agarose gel (agarose concentration $-2 \%$, running buffer $-1 \mathrm{x}$ TBE). Amplicon sizes estimated were performed using the Gene Ruler 100 bp DNA Ladder (Thermo Fisher Scientific).

\section{Results and discussion}

According to the research, the OPO-16C marker is identified in strawberry hybrid forms 932-29 (F. virginiana subsp. platypetala (Rydb.) Staudt $\times$ Feyerverk), 933-4 (F. virginiana subsp. platypetala (Rydb.) Staudt $\times$ Rubinovyy kulon), 62-7, 62-41 (Bylinnaya $\times$ Feyerverk), 72-24, 72-71 (Privlekatelnaya $\times$ Bylinnaya), 65-17, 65-24 (Olimpiyskaya nadezhda $\times$ Bylinnaya) and 69-29 (Feyerverk $\times$ Bylinnaya) (Figure 1., Table).

In addition to the target fragment $285 \mathrm{bp}$, all studied strawberry genotypes also contain additional fragments of the OPO-16C marker. Amplification of additional fragments of the OPO-16C marker is also confirmed by other researchers. These fragments are synthesized in any strawberry forms and are not diagnostic signs of the allelic state of the Rpfl gene $[13,14]$. 


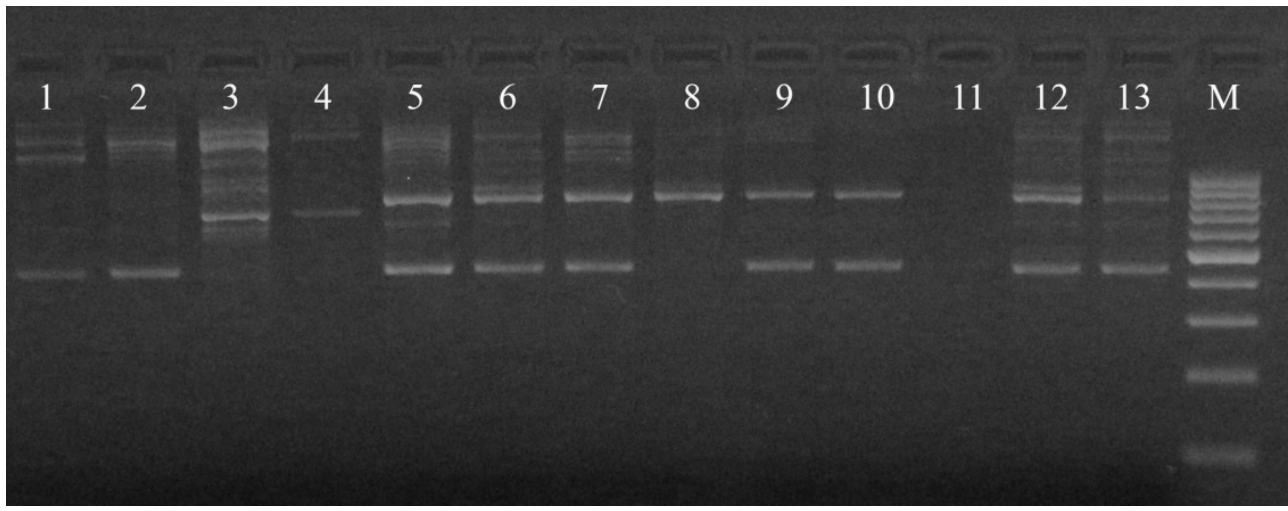

Fig. 1. Electrophoretic profiles of marker fragments (OPO-16C) of the Rpfl gene in strawberry hybrid forms

1 - 933-4, 2 - 932-29, 3 - 62-23, 4 - 65-2, 5 - 69-29, 6 - 62-7, 7 - 62-41, 8 - 65-15, 9 - 72-24, $10-72-71,11-35-16,12-65-17,13-65-24, \mathrm{M}$ - Molecular weight marker

The marker SCAR-R1A was identified in strawberry seedlings 69-29 (Feyerverk $\times$ Bylinnaya), 62-41 (Bylinnaya $\times$ Feyerverk), 72-24, $72-71$ (Privlekatelnaya $\times$ Bylinnaya), 65-17, 65-24 (Olimpiyskaya nadezhda $\times$ Bylinnaya) (Figure. 2., Table.).

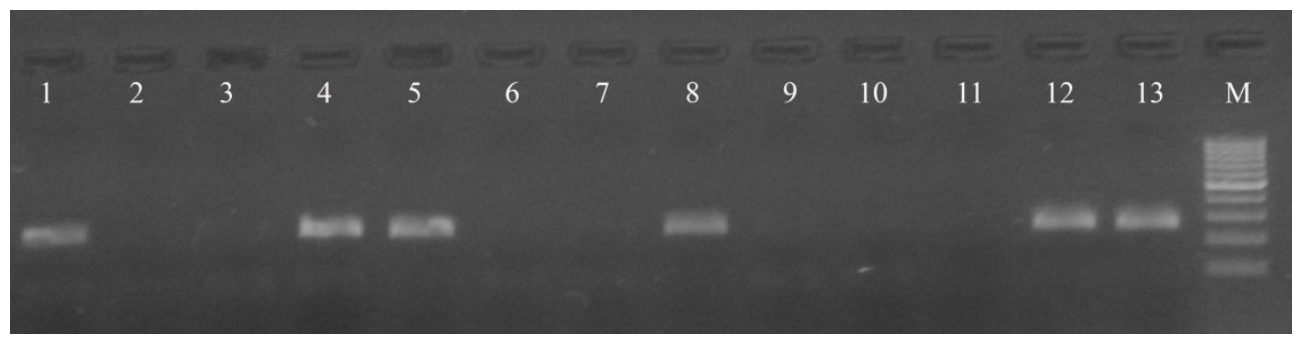

Fig. 2. Electrophoretic profiles of marker fragments (SCAR-R1A) of the Rpf1 gene in strawberry hybrid forms

1 - 69-29, 2 - 933-4, 3 - 932-29, 4 - 62-41, 5 - 72-24, 6 - 62-7, 7 - 62-23, 8 - 72-71, 9 - 65-2, $10-65-15,11-35-16,12-65-17,13-65-24, \mathrm{M}-$ Molecular weight marker

Table. Allelic polymorphism of the Rpf1 red stele root rot resistance gene in strawberry hybrid forms ( 1 - allele is present, 0 - allele is absent)

\begin{tabular}{|c|c|c|c|c|}
\hline Genotype & Origin & $\begin{array}{l}\text { Marker } \\
\text { SCAR-R1A } \\
\end{array}$ & $\begin{array}{l}\text { Marker } \\
\text { OPO-16C }\end{array}$ & Putative genotype \\
\hline $933-4$ & $\begin{array}{l}F . \quad \text { virginiana } \\
\text { (Rydb.) Staudt } \times \text { Rubinovyy kulon }\end{array}$ & 0 & 1 & rpflrpfl \\
\hline $932-29$ & $\begin{array}{ll}F . \quad \text { virginiana } & \text { subsp. platypetala } \\
(\text { Rydb.) Staudt } \times \text { Feyerverk }\end{array}$ & 0 & 1 & rpflrpfl \\
\hline $69-29$ & Feyerverk $\times$ Bylinnaya & 1 & 1 & Rpflrpf1 \\
\hline $62-7$ & \multirow{3}{*}{ Bylinnaya $\times$ Feyerverk } & 0 & 1 & rpflrpfl \\
\hline $62-23$ & & 0 & 0 & rpflrpfl \\
\hline $62-41$ & & 1 & 1 & Rpflrpfl \\
\hline $72-24$ & \multirow{2}{*}{ Privlekatelnaya $\times$ Bylinnaya } & 1 & 1 & Rpflrpfl \\
\hline 72-71 & & 1 & 1 & Rpflrpfl \\
\hline $65-2$ & \multirow{4}{*}{ Olimpiyskaya nadezhda $\times$ Bylinnaya } & 0 & 0 & rpflrpfl \\
\hline $65-15$ & & 0 & 0 & rpflrpfl \\
\hline $65-17$ & & 1 & 1 & Rpf1rpf1 \\
\hline $65-24$ & & 1 & 1 & Rpflrpfl \\
\hline $35-16$ & $922-67 \times$ Maryshka & 0 & 0 & rpflrpfl \\
\hline
\end{tabular}


The obtained data indicate the heterozygous state of the Rpfl gene in strawberry forms 62-41 (Bylinnaya $\times$ Feyerverk), 72-24, $72-71$ (Privlekatelnaya $\times$ Bylinnaya), 65-17, 65-24 (Olimpiyskaya nadezhda $\times$ Bylinnaya) and 69-29 (Feyerverk $\times$ Bylinnaya) (markers OPO$16 \mathrm{C}$ and SCAR-R1A are present in the genotype). Strawberry seedlings 932-29 (F. virginiana subsp. platypetala (Rydb.) Staudt $\times$ Feyerverk), 933-4 (F. virginiana subsp. platypetala $($ Rydb.) Staudt $\times$ Rubinovyy kulon) and 62-7 (Bylinnaya $\times$ Feyerverk) are characterized by the recessive homozygous state of the Rpfl (only marker OPO-16C is present in the genotype). Strawberry seedlings 62-23 (Bylinnaya $\times$ Feyerverk), 65-2, 65-15 Olimpiyskaya nadezhda $\times$ Bylinnaya) and 35-16 $(922-67 \times$ Maryshka $)$ also are characterized by the recessive homozygous state of the Rpf1 (both markers are absent in the genotype).

Other researchers have also identified selected strawberry forms with the Rpf1 resistance allele in the genome: CPRO 90025, MD683, MDUS 3184 and Yalova-15 (heterozygous genotype), CPRO 88239, CPRO 88246, CPRO 88275 and Yalova-4 (homozygous genotype) [8]. The identification of homozygous for the Rpfl gene strawberry forms is of great practical importance, making it possible to obtain up to $100 \%$ resistant seedlings when used in hybridization. The use of homozygous forms in crossing will theoretically avoid the need for phenotypic or genotypic analysis of hybrid seedlings for a selective trait, which will reducing the analysis time, labor and financial costs. [15].

Analysis of the origin of the studied strawberry hybrid seedlings confirmed the data of molecular genetic testing. Strawberry seedlings 69-29 (Feyerverk $\times$ Bylinnaya), 62-41 (Bylinnaya $\times$ Feyerverk), 72-24, 72-71 (Privlekatelnaya $\times$ Bylinnaya), 65-17, 65-24 (Olimpiyskaya nadezhda $\times$ Bylinnaya), characterized by the presence of both markers in the genome and, therefore, the heterozygous state of the Rpfl gene, were isolated in crossing combinations, where the donor of the functional Rpfl allele is the Bylinnaya variety, and other parental genotypes (Olimpiyskaya nadezhda, Privlekatelnaya and Feyerverk) do not have the functional Rpfl allele [16]. In this regard, strawberry hybrids with the identified $R p f 1$ gene can only have a heterozygous genotype (Rpflrpfl). In the future, the selected hybrid seedlings will be crossed to obtain strawberry forms homozygous for the Rpfl gene.

\section{Conclusion}

Thus, in the result of the research we analyzed the allelic polymorphism of the Rpfl gene in strawberry hybrid seedlings. The perspective strawberry forms (69-29 (Feyerverk $\times$ Bylinnaya), 62-41 (Bylinnaya $\times$ Feyerverk), 72-24, 72-71 (Privlekatelnaya $\times$ Bylinnaya), 65-17, 65-24 (Olimpiyskaya nadezhda $\times$ Bylinnaya)), characterized by resistance to red stele root rot (putative genotype Rpflrpfl) were identified.

\section{References}

1. A. Sasnauskas, R. Rugienius, D. Gelvonauskiené, I. Zalunskaitè, G. Stanienè, T. Siksnianas, V. Stanys, C. Bobinas, Acta Hortic., 760, 165-169 (2007) https://doi.org/10.17660/ActaHortic.2007.760.21

2. Z. Chen, J. Huang, J. Zhao, H. Liang, Biotechnology Bulletin, 33(3), 37-44 (2017) https://doi.org/10.13560/j.cnki.biotech.bull.1985.2017.03.006

3. K.J.D. Hughes, A.J. Inman, D.E.L. Cooke, EPPO Bulletin, 30(3-4), 533-538 (2000)

4. A.C. Newton, J.M. Duncan, N.H. Augustin, D.C. Guy, D.E.L. Cooke, Plant pathology, 59(3), 472-479 (2010) https://doi.org/10.1111/j.1365-3059.2010.02273.x 
5. R. Gao, Y. Cheng, Y. Wang, Y. Wang, L. Guo, G. Zhang, Genome announcements, 3(2), e00034-15 (2015) https://doi.org/10.1128/genomeA.00034-15

6. W.E. Van de Weg, Theoretical and Applied Genetics, 94(3-4), 445-451 (1997) https://doi.org/10.1007/s001220050435

7. V.M. Whitaker, Journal of Berry Research, 1, 115-127 (2011) https://doi.org/10.3233/BR-2011-013

8. K.M. Haymes, W.E. Van de Weg, P. Arens, J.L. Maas, B. Vosman, A.P.M. Den Nijs, J. Amer. Soc. Hort. Sci., 125(3), 330-339 (2000) https://doi.org/10.21273/JASHS.125.3.330

9. R. Rugienius, T. Siksnianas, V. Stanys, D. Gelvonauskiene, V. Bendokas, Agronomy research, 4, 335-339 (2006)

10. I.V. Luk'yanchuk, A.S. Lyzhin, I.I. Kozlova, Vavilov Journal of Genetics and Breeding, 22(7), 795-799 (2018) https://doi.org/10.18699/VJ18.423

11. A.S. Lyzhin, I.V. Lukyanchuk, E.V. Zhbanova, Proceedings on Applied Botany, Genetics and Breeding, 180(1), 73-77 (2019) https://doi.org/10.30901/2227-88342019-1-73-77

12. K.M. Haymes B. Henken, T.M. Davis, W.E. van de Weg, Theor. Appl. Genet., 94(8), 1097-1101 (1997) https://doi.org/10.1007/s001220050521

13. M. Sturzeanu, M. Coman, M. Ciuca, I. Ancu, D. Cristina, A.G. Turcu, Acta Hortic., 1139, 107-112 (2016) https://doi.org/10.17660/ActaHortic.2016.1139.19

14. D. Gelvonauskienè, R. Rugienius, T. Šikšnianas, G. Stanienè, A. Sasnauskas, V. Stanys, Zemdirbyste/Agriculture 94(4), 139-145 (2007)

15. I.O. Baumgartner, A. Patocchi, J.E. Frey, A. Peil, M. Kellerhals, Plant Mol Biol. 33, 1573-1583 (2015) https://doi.org/10.1007/s11105-015-0858-x

16. A.S. Lyzhin, I.V. Luk'yanchuk, Proceedings of the National Academy of Sciences of Belarus. Agrarian Series, 58(3), 311-320 (2020) https://doi.org/10.29235/1817-72042020-58-3-311-320 